\title{
高層建築物の風直角方向弾塑性応答性状について \\ PROPERTIES OF ELASTO-PLASTIC RESPONSES OF A TALL BUILDING IN ACROSS-WIND DIRECTION
}

\author{
大熊武司*，二宮正行** \\ Takeshi OHKUMA and Masayuki NINOMIYA
}

\begin{abstract}
This paper discusses following subjects related to elasto-plastic behaviors of tall buildings for across wind action by numerical response analysis with multi-mass models with equivalent shearing stiffness.

Firstly, to clarify the applicablity of the suggested response analysis method with one-mass model, effects of higher mode vibrations and changes of mode shapes with the progress of structural yielding are examined. Secondly, the applicability of the mode correction factor which is often used in a case of elastic response analysis is examined. And lastly, energy distribution properties for elastic and elasto-plastic vibrations are discussed, and a simple estimation method is presented.
\end{abstract}

Obtained major findings are as follows;

1. Effects of higher mode vibrations and changes of the first mode shapes are very small.

2. The mode correction factor about the first generalized wind force, which has been used is elastic response analysis, is applicable for elasto-plastic response analysis.

3. Distributions of total input energy are approximately similar to them in elastic responses except for peculiar cases of distribution of the elastic limit of inter story deflection in bending type buildings.

\author{
keywords : multi-mass model, elasto-plastic response, across-wind vibration, higher mode vibration, \\ mode correction, energy distribution \\ 多質点系, 弾塑性応答, 風直角方向振動, 高次振動, モード補正, エネルギー配分
}

\section{1 . 序}

建築物の高層化に伴い、主骨組の全てあるいは大半が風荷重によっ て決定される建築物が增えている。しかし、現行の耐風設計において は、想定される最大級の強風時においても建築物の挙動をほほ弾性範 囲内に収めることが求められている。他方、設計法の合理化の観点か ら、性能設計あるいは損傷制御設計といった設計概念が受け入れられ はじめ、耐風設計についても、設計風速を超えた風速域での構造物の 安全性に対する信頼性、終局強度を考慮した弾塑性設計、履歴エネル ギー吸収型の制振システムによる建築物の応答制御、それら制振シス テムの耐風安全性等に対する関心が高まりつつあるり。

実際、塑性化の大きな範囲までを対象とした建築物の風外乱に対す る弾塑性挙動の特性およびその予測手法についての研究も行われるよ うになってきた。筆者の一人を含む辻田ら2ータは、「直接積分法によ る吸収エネルギー值と変位振幅波形のゼロクロスピーク值分布法によ る吸収エネルギー値の一致という考え方によって、先ず、弾塑性応答 時のゼロクロスピーク值分布と等価線形系の構造特性値を確定し、次 に、その結果を用いて他の諸応答量を求める」という手法により、弾 塑性応答の確率・統計的予測手法について一連の成果を得ている。た だし、予測手法の検討に重点を置いていることより、応答性状の把握 のための風速レベルは一定として、降伏強度を変え、多質点モデルに
よる解析時の 1 次振動モードも直線形の一通りに限っている。山崎らの は、完全弾塑性建築物のモーダル1次振動を対象として、風力のパ ワースペクトル密度と弾塑性構造物のエネルギー入力の関係を定式化 し、降伏レベルとエネルギー応答の関係を検討している。安井ら》は、 8 層 1スパンの鋼構造建築物について、部材および接合パネルのレベ ルで応答性状を考察している。

筆者ら ${ }^{81.99}$ も、以下の方針に従って、先ず風直角方向振動について モーダル1次1質点モデルによる検討を済ませている。本論文の構成 に必要な一部の成果を 4.1 に示す。

(1)「風力スペクトルとエネルギースペクトルを関係づけ、等価線形系 におけるエネルギーと応答の関係を利用した簡便な応答予測法を導 く」ことを研究の目的とする。従って、辻田らと異なり、筆者らの手 法では、ビロクロスピーク值分布を求めることができないが、近似的 手法を目指す場合には、この点は必ずしも大きい欠点とはならない8)。 (2)建物形状は、「剥離型の平面形状を有する建築物の場合、応答変位 が最大を示す風向角における変位応答性状は平面形状によらずほほ 同様の傾向を示す」10)ことを考慮して、標準的な例としてアスペク ト比 5 の正方形平面の一様な柱状体とする。

(3)復元力特性は Normal Bi-Linear 型とし、弾性限界は層間変形角の値 で規定する。
本論文は文献16)に加筆したものである。

* 神奈川大学工学部建築学科 教授・工博

** 構造計画研究所構造設計部 (当時, 神奈川大学 大学院生)
Prof., Dept. of Architecture, Faculty of Engineering, Kanagawa University, Dr. Eng. Structural Design Dept., Kozo Keikaku Engineering Inc. 
(4)外力は、弾性限界風速を基準として、その倸数倍風速時に想定され る風力として与える。なお、「風速」は平均風速を意味し、風速値 は共振風速以下とする。

(5) 風力のパワースペクトル密度と入力エネルギーの関係を明らかに し、等価線形系の概念に基づく簡便な応答予測法を検討する。

本研究は、以上に続くものとして、ロッキング型, せん断型および 曲げ型の各種多質点モデルの応答解析により、高次振動の影響、塑性 化による振動モードの変化、1質点系による応答評価の妥当性、弾塑 性応答に対する「モード補正係数」の適用性、入力エネルギーの分布 性状等の諸問題を、コンピュータシミュレーション手法により体系的 に検討したものである。なお、本論文では、1次振動モードが直線形 の振動系をロッキング型振動系と呼ぶ。

\section{2. 解新方脑}

\section{1 嗮新天テル}

振動モデルは、風による振動では一般に1次振動が支配的になるこ とを考慮して、図1に示すように対象建築物を 6 質点系とし、以下の 仮定に基づきモデル化する。(1)各層の剛性はせん断剛性で評価する (ただし、曲げ型の建築物については等価せん断剛性で評価する)。(2) 各質点の質量は等しい。ただし、頂部質点は他の $1 / 2$ とする。(3)各質 点間距離 $\Delta h_{i}$ は等しい。(4)減衰係数は初期剛性比例型とし、1 次隇衰 定数らは は2\%とする。ただし、高次振動に対する減衰の影筙を考虑し て、無次元弾性限界風速 6 の場合について（7参照）、レイリー型 $\left(\zeta_{1}=\zeta_{2}=2 \%\right)$ とした場合について検討する。(5)各層の復元力特性は、 図 2 に示すようにNormal Bi-Linear 型とし、初期剛性に対する 2 次剛 性の比 $\alpha$ は 0.5 とする。 $\alpha=0.5$ の選択は、文献(9)および後述 4.1 節の 結果でわかるように、評価対象量によって程度の差はあるが、 $\alpha=0.25$, $0.5,0.75$ のいずれの場合とも同様の傾向を示し、 $\alpha=0.5$ の場合がその

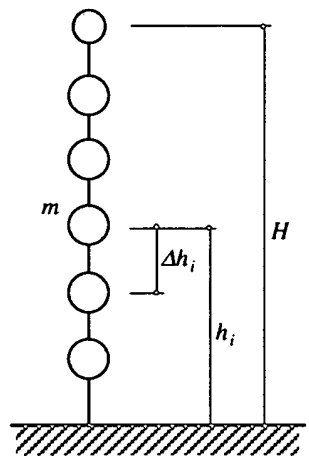

图 1 浱钩モデル

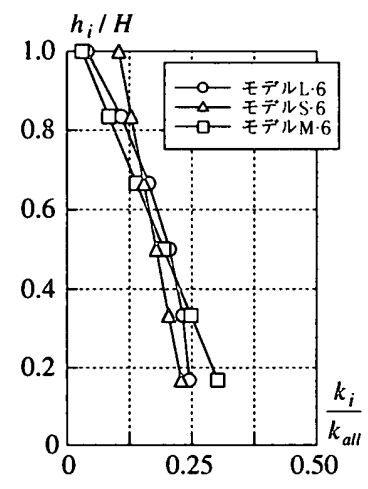

图 5 甽经分菖

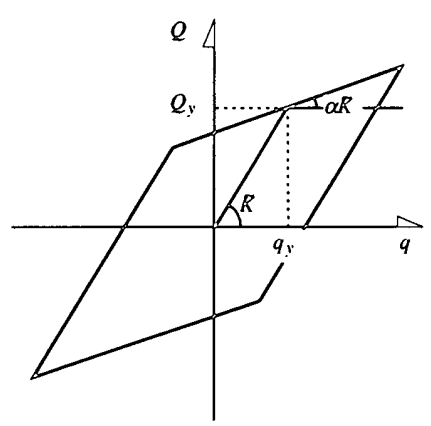

图 2 復元放等征
图 31 次哏鈞モード

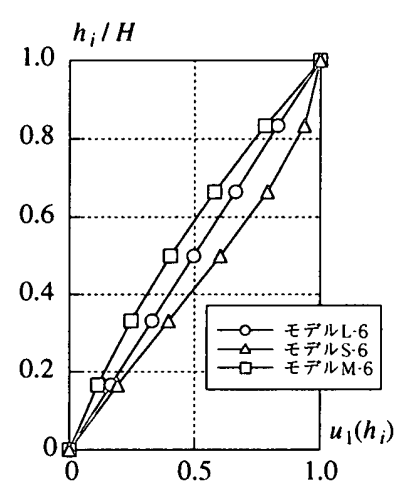

平均的な性状を示すことによるが、高次振動に対する2次剛性比の影 㸷を考虑して、無次元弾性限界風速6の場合について、 $\alpha=0.25$ とした 場合を検討する。(6)降伏変形量 $q_{y}$ は基本的に降伏層間変形角 $q_{y} / \Delta h=1 / 300$ に相当する値とし、この時の層間变形角を弾性限界層間 変形角 $R_{e}$ と呼ぶ。(7)多質点系における弾性限界風速 $U_{e}$ は、ある層の 応答層間変形角が降伏層間変形角に達する風速と定義し、本論文で は、無次元弾性限界風速 $U_{e}^{*}((2)$ 式参照) の值4 9について解析する。 なお、4.1節に述べるように、無次元弾性限界風速を固定した場合、弾 性限界首間変形角 $R_{e}$ の影響は、建築物の構造密度 $\rho_{s}$ の影響として読 み替えることが出来るので (後述(8)式参照)、特定の值の選択は、以 下の結果を限定しない。

以上の仮定のもとに、本研究では、ロッキング型、せん断型、曲げ 型の3つの多質点モデルを基本モデルとして解析する。表1に基本モ デルのR $R_{e}$ と基本モデルに対応する1質点系の $R_{e}, \alpha$ を示す。表中、モ デル名の最後尾 1,6は、それぞれ1睤点系,6質点系を表す。更にfは、

\section{表 1 触新モデルの設定}

\begin{tabular}{|c|c|c|c|}
\hline \multicolumn{2}{|c|}{ 振動系 } & $R_{e}$ & $\alpha$ \\
\hline \multirow{2}{*}{ ロッキング型 } & モデル L-6 & 全層 $1 / 300$ & 0.5 \\
\hline & モデル L-1 & $1 / 300$ & 0.5 \\
\hline \multirow{3}{*}{ せん断型 } & モデル S-6 & 全層 $1 / 300$ & 0.5 \\
\hline & モデル S-1 & $1 / 300$ & 0.5 \\
\hline & モデル S-1f & $1 / 340$ & 0.5 \\
\hline \multirow[t]{3}{*}{ 曲げ型 } & モデル M·6 & $\begin{array}{c}\text { 1～4層 } 1 / 300 \\
5 \text { 層 } 1 / 200 \\
\text { 6層 } 1 / 100 \\
\end{array}$ & 0.5 \\
\hline & モデル M-1 & $1 / 300$ & 0.5 \\
\hline & モデル M-1f & $1 / 250$ & 0.52 \\
\hline
\end{tabular}
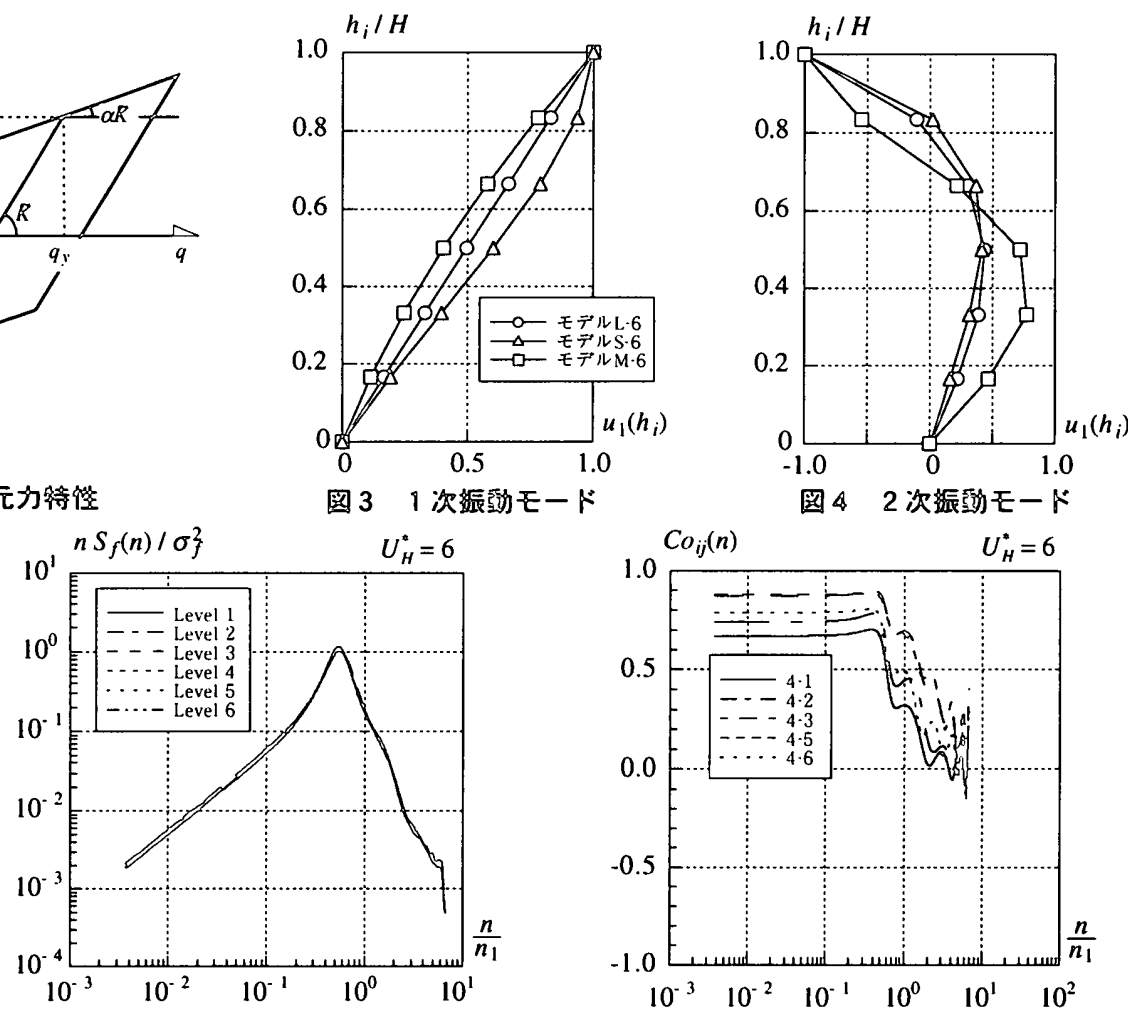

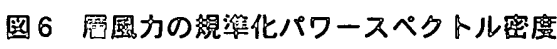

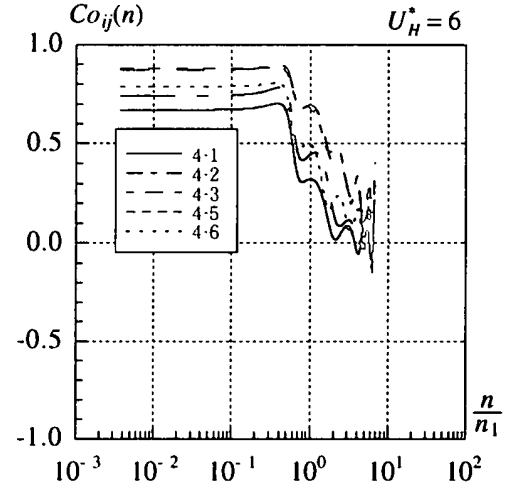

图 72 層間のコ・コヒーレンス 
1 質点系の静的載荷における外力と頂部变形の関倸を6質点系のそれ (3節参照)に近似的に一致させた場合の $R_{\varphi} ， \alpha$ を用いたモデルのこと である。図3に基本モデルの1次振動モード、図4に2 次振動モード、 図 5 には次振動モードに対応する剛性分布を示す。図 5 中の $k_{\text {all }}$ は各 層の剛性 $k_{i}$ の総和 $\sum_{i=1}^{\infty} k_{i}$ を表している。なお、多質点系と比較する 1 質点系の質量および初期剛性は、各基本モデルの1次振動モードに対 するモーダル質量およびモーダル初期剛性とする。

風力モデルは、動的天秤実験より得られた風直角方向変動転倒モー メントのパワースペクトル密度を基に、文献(11)の手法に従いシミュ レートした多層同時層風力とする。図6にシミュレーション結果の1 例として、無次元風速6の場合の層風力の規準化パワースペクトル密 度(各層同一と仮定)を、図7に2層間のコ・コヒーレンスの例を示す。

\section{2 基礎方程式と計算・評価方法}

\subsection{1 基礎方程式}

弾塑性復元力特性を有する多質点系に風外力が作用した場合の振動 方程式は(1)式で表される。

$$
[M]\left\{\ddot{x}_{n}\right\}+[C]\left\{\dot{x}_{n}\right\}+\left\{Q\left(x_{n}\right)\right\}=\frac{1}{2} \rho U_{H}^{2} B[a]\left\{C_{f n}\right\}
$$

ただし、 $[M]$ : 質量マトリックス, $[C]$ : 減衰係数マトリックス, $\left\{x_{n}\right\}$ : $t=t_{n}$ における変位ベクトル, $\left\{Q\left(x_{n}\right)\right\}: t=t_{n}$ における復元力ベクトル， $\rho$ : 空気密度, $U_{H}$ : 建築物頂部風速, $B$ : 建築物の見付け幅, $[a]:$ 各層の 負担高さマトリックス, $\left\{C_{f_{n}}\right\}: t=t_{n}$ における層風力係数ベクトル， ドットは時間 $t$ に関する微分。

本研究では、(2)式に定義する無次元量を導入して(1)式を無次元化し た(3)式により応答解析を行う。ここで、式中の*は無次元量であるこ とを表す(以下同様)。

$$
\begin{aligned}
& t^{*}=\frac{t}{T_{1}}, x^{*}=\frac{x}{H}, \dot{x}^{*}=\frac{\dot{x}}{n_{1} H}, \ddot{x}^{*}=\frac{\ddot{x}}{n_{1}^{2} H}, m^{*}=\frac{m}{\bar{M}_{1}} \\
& k^{*}=\frac{k}{R_{1}}, U_{H}^{*}=\frac{U_{H}}{n_{1} B} \\
& {\left[M^{*}\right]\left\{\ddot{x}_{n}^{*}\right\}+4 \pi \zeta_{1}\left[K^{*}\right]\left\{\dot{x}_{n}^{*}\right\}+(2 \pi)^{2}\left\{Q^{*}\left(x_{n}^{*}\right)\right\}} \\
& =\frac{1}{2} \frac{\rho}{\rho_{s}} \frac{B}{H} \frac{1}{\Lambda} U_{H}^{*}[a]\left\{C_{f n}\right\}
\end{aligned}
$$

ただし、 $T_{1}: 1$ 次固有周期, $n_{1}: 1$ 次固有振動数, $H$ : 建築物頂部高さ, $m$ : 質点の質量, $k$ : 層の初期剛性, $\tilde{M}_{1}: 1$ 次モータル質量, $\tilde{K}_{1}: 1$ 次モ一 タル初期剛性, $\left[K^{*}\right]$ : 無次元初期剛性マトリックス, $\rho_{s}:$ 建築物の構 造密度 $\left(=m_{i} / B^{2} a_{i}\right),\left\{Q^{*}\left(x_{n}^{*}\right)\right\}=\left\{Q\left(x_{n}\right)\right\} / H R_{1}, \Lambda=\left\{u_{1}\right\}^{T}[a]\left\{u_{1}\right\} \quad\left(\left\{u_{1}\right\}: 1\right.$ 次振動モードベクトル)を表す。
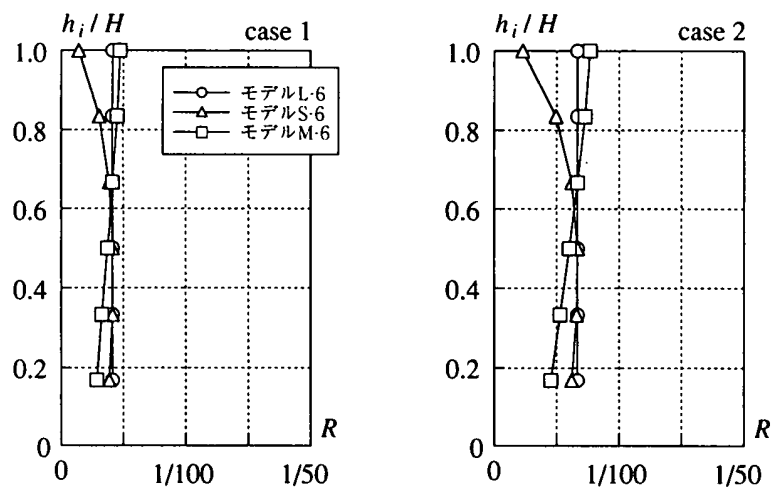

図 8 各層の層間变形角（弾性系）
エネルギーの釣合式は、(3)式の両辺に左から $\left\{\dot{x}_{n}^{*}\right\}^{T} d t^{*}$ を乗じ、0か

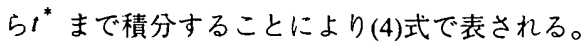

$$
\begin{gathered}
\int_{0}^{t^{*}}\left\{\dot{x}_{n}^{*}\right\}^{T}\left[M^{*}\right]\left\{\ddot{x}_{n}^{*}\right\} d t^{*}+\int_{0}^{t^{*}} 4 \pi \zeta_{1}\left\{\dot{x}_{n}^{*}\right\}^{T}\left[K^{*}\right]\left\{\dot{x}_{n}^{*}\right\} d t^{*} \\
+\int_{0}^{t^{*}}(2 \pi)^{2}\left\{\dot{x}_{n}^{*}\right\}^{T}\left\{Q^{*}\left(x_{n}^{*}\right)\right\} d t^{*} \\
=\int_{0}^{*^{*}} \frac{1}{2} \frac{\rho}{\rho_{s}} \frac{B}{H} \frac{1}{\Lambda} U_{H}^{* 2}\left\{\dot{x}_{n}^{*}\right\}^{T}[a]\left\{C_{f n}\right\} d t^{*}
\end{gathered}
$$

まだ(4)式は無次元入力エネルギー $E^{*}$ 、無次元減衰エネルギー $E_{h}^{*}$ 、無次元塑性歪エネルギー $E_{p}^{*}$ 、無次元弾性エネルギー $E_{e}^{*}$ を用い て(5)式のように表すことができる(2)。なお、無次元エネルギーと有次 元エネルギーは(6)式で結ばれている。

$$
E_{h}^{*}+E_{p}^{*}+E_{e}^{*}=E^{*} \quad \text { (5) } \quad E^{*}=\frac{E}{\bar{M}_{1}\left(n_{1} H\right)^{2}}
$$

\subsection{2 計算方法と評価方法}

時刻歴応答解析は線形加速度法を用いた直接積分による方法で行 う。この時の時間刻み $\Delta t$ は、建築物の 1 次固有周期の $1 / 100$ (3 次固有 周期の約 $1 / 25$ に相当)とする。因に 6 次固有周期の約 $1 / 13$ であり、応 答解析の安定性に問題はない13)。応答の評価時間 $T^{*}$ は 1 次固有周期 の 150 倍とし、応答值は、各無次元風速ごとに $t^{*}=0 \sim 1550$ の計算結 果を解析開始点からの漸増部分 $t^{*}=0 \sim 50$ を除いた $T^{*}=150$ の 10 波 に分解し、それぞれの応答值のアンサンブル平均値とする。

\section{3 . 基本モデルの静的変形性状}

応答計算に先立って、基本モデルの弾性系抢よび弾塑性系につい て、逆三角形分布荷重による静的載荷により静的変形性状を把握す る。弾性系の静的載荷および弾塑性系の静的漸増載荷による各層の層 間変形角 $R$ をそれぞれ図 8 , 図 9 に、弾塑性系の外力と頂部変形関倸 を図 10 に示す。なお、図 8,9中の casel, case2 は、ある層が降伏する 時の外力を $F_{y}$ として、それぞれ $1.25 F_{y}$ および $2.0 F_{y}$ に相当する外力 を載荷した結果である。弾性系では全てのモデルが1次振動形に合っ た変形性状を示している。弾塑性系については、モデルL-6は全層ほ ほ同時に塑性化するため、層間変形角は弾性系と同様高さ方向に一定 である。モデル S-6は変形の大きい下層部から塑性化がはじまるが、 層間変形角の分布性状は概ね弾性系に一致している。外力と頂部変形 関係は、モデルS-1に比べモデルS-1fは6質点系に良く一致している。
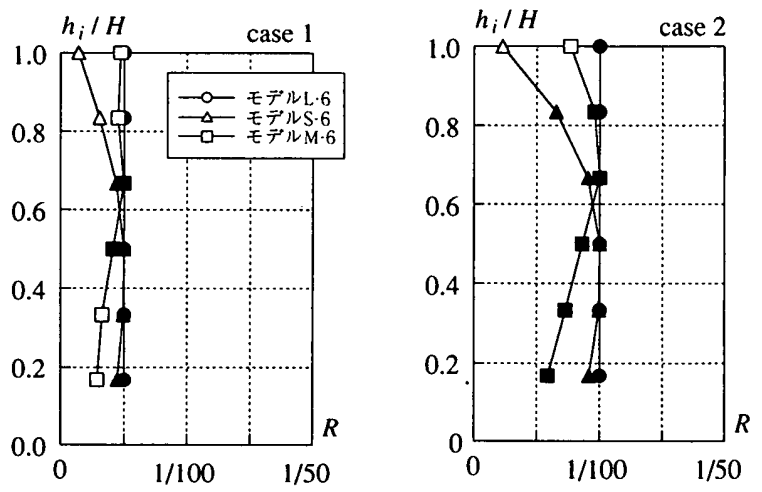

※図中プロット黒塗りは降伏を表す

図 9 各層の層間変形角（弾塑性系） 

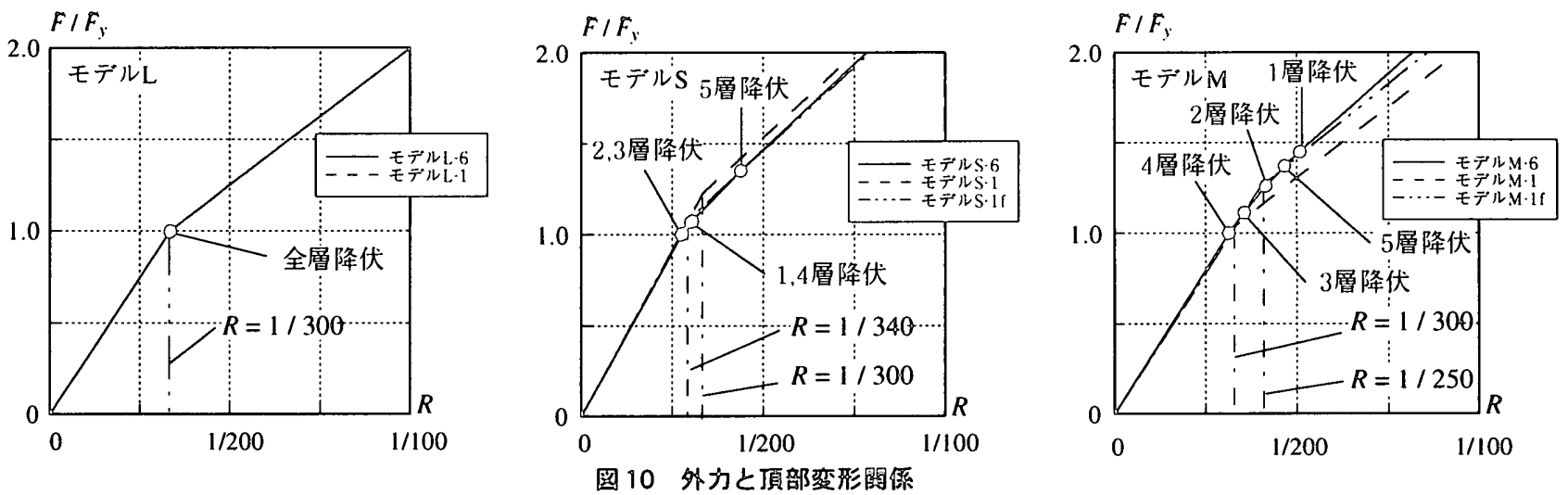

モデルM-6は上部2層の塑性化を抑えたために、第4層から塑性化が 始まり、第 4 層の層間变形角が上部 2 層に比べ大きくなる。また、外 カと頂部変形関係では、モデル M-1に比べモデル M-1fは6質点系に 概ね一致している。

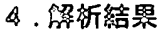

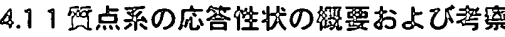

1 質点系の弾塑性応答性状の概要を、モデル L-1 を例として弾性限 界層間変形角 $1 / 300$ 、無次元弾性限界風速 6 、減衰定数 $2 \%$ の場合の弾 塑性応答量およびエネルギー応答量を、初期剛性に対する2次剛性の 比 $\alpha$ をパラメータとして示す。なお、本項における風外力は、動的天 秤実験より得られた変動転倒モーメントのパワースペクトル密度をシ ミュレートしたものである。なお、図中の” Elast”は弾性応答解析結 果である。

図 11 に弾性時および弾塑性時の応答変位のレベルクロッシング数 $v_{e} と v_{p}$ の比 $v_{p} / v_{e}$ と風速の関係を示す。(図中の $\triangle \sum^{2}$ 無次元共振風 速を表す(以下同樣))。 $\alpha$ の違いによらず值は風速の増加に対し隇少し ており、塑性化による長周期化の傾向が見ら れる。またここの傾向は $\alpha$ の低下に伴い大きく なる。図 12 に応答変位の標準偏差 $\sigma_{q^{*}}$ と風速 の関係を示す。弾塑性応答值は、履歷減衰によ る振動抑制により弾性値を下回り、その傾向 は、 $\alpha$ の低下に伴い大きくなる。図13に塑性率 $\mu$ と風速の関係を、図 14 に累積塑性変形倍率 $\eta$ と風速の関係を示す。ここで、塑性率は応答 変位の最大值を降伏変形量で除した值を表し、 累積塑性変形倍率は正側もしくは負側のどち らか大きい方の塑性変形量の累積值を降伏変
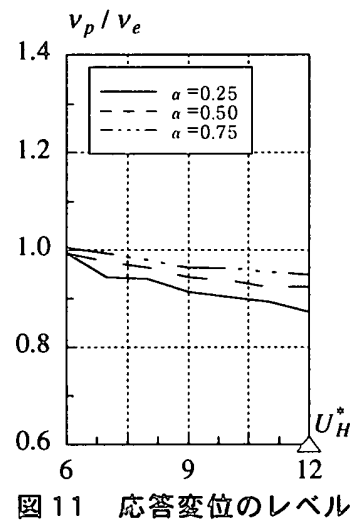
クロッシング䍉

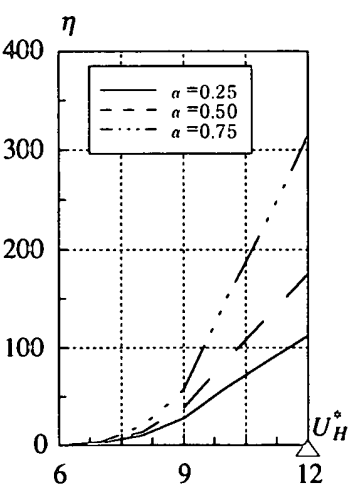

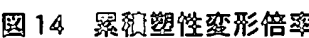

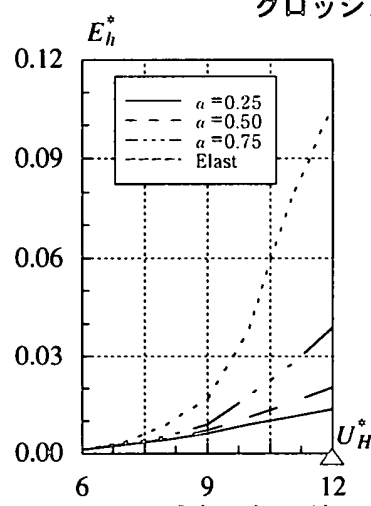

图 15 涯衰エネルドー
形量で除した值を表す。 $\mu$ と $\eta$ のいずれも風速および $\alpha$ の増加に伴い 大きくなる傾向にある。なお、 $\eta$ が 10 程度となる風速は、無次元弾性 限界風速の違いににもよるが1.25U $U_{\rho}^{*} \sim 1.35 U_{\rho}^{*}$ 程度である。図15 17 に無次元減衰エネルギー $E_{h}^{*}$ 、無次元塑性歪エネルギー $E_{p}^{*}$ 、無次 元総入力エネルギー $E^{*}$ と風速の関倸を示す。ただし、弾性エネル ギーは総入力エネルギーに比べ微小であるため、ここでは総入力エネ ルギーを $E_{h}^{*}+E_{p}^{*}$ とする。 $E_{h}^{*}$ は風速の増加に伴い増加し、 $\alpha$ の低下に 伴い小さくなる。また、全ての風速範囲において弾性値を下回ってい る。 $E_{p}^{*}$ も同様に風速の増加に伴い増加するが、 $\alpha$ の低下に伴い大きく なる。他方、 $E^{*}$ は風速の増加に伴い増加するものの、 $\alpha$ への依存性は 小さい。従って、エネルギーの吸収量は変化せず吸収機構の負担する 割合が変化するだけと考えられる。以上の傾向は無次元弾性限界風速 の違いによらない。

以上、弾性限界層間変形角 $1 / 300$ として、応答特性を要約したが、 この傾向は弾性限界層間変形角の值に依存しない。この点を以下に理 論的に明らかにしておく。

簡単のために、ロッキング型 1 質点弾塑性系を例とし、1 質点弾塑

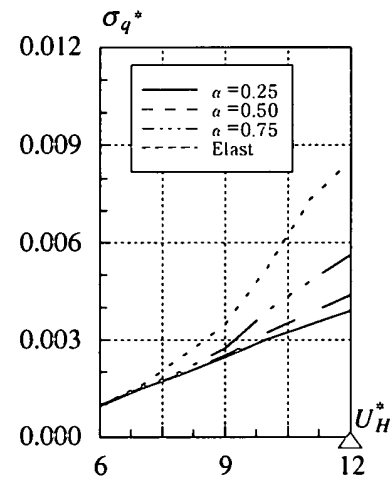

图 12 応答变位の德算偏差

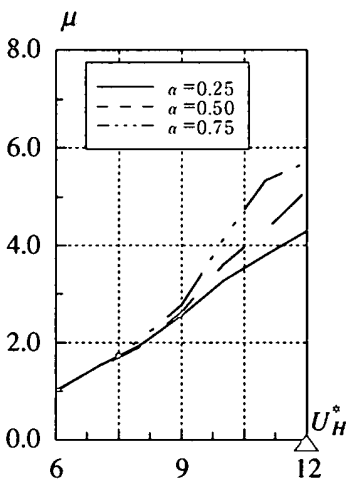

图 13 塑性骓

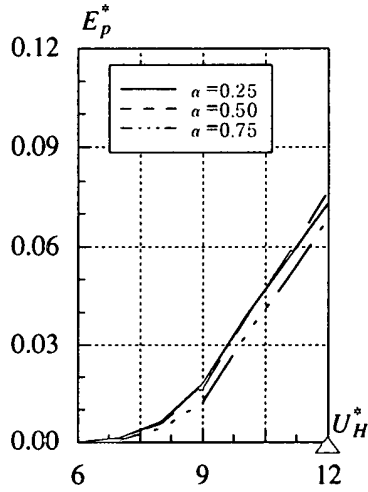

图 16 塑僬歪エネルキー

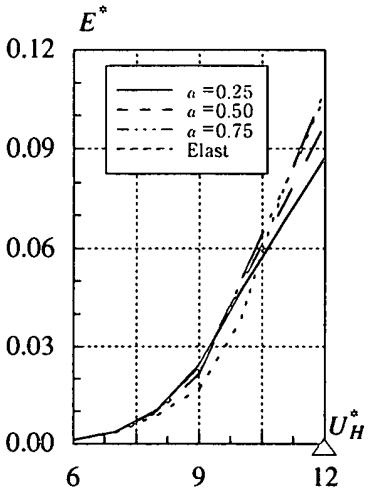

图 17 棇入力エネルギー 
性系の無次元振動方程式は(7)式で表される。

$$
\ddot{q}_{n}^{*}+4 \pi h \dot{q}_{n}^{*}+(2 \pi)^{2} \mathscr{Q}^{*}\left(q_{n}^{*}\right)=\frac{3}{2} \frac{\rho}{\rho_{s}} \frac{B}{H} U_{H}^{* 2} C_{m n}
$$

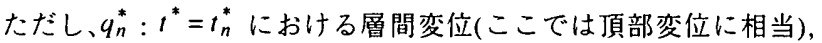
$C_{m n}: t^{*}=t_{n}^{*}$ における転倒モーメント係数。

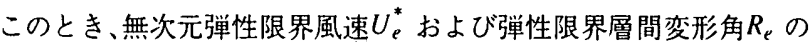
定義より、Reは次式の様に表せる。

$$
R_{e}=\frac{3}{2} \frac{\rho}{\rho_{s}} \frac{B}{H} U_{e}^{* 2} C_{m}^{\prime} C\left(S_{m e}^{*}, h\right)
$$

$C_{m}^{\prime}$ : 変動転倒モーメント係数, $S_{m e}^{*}:$ 転倒モーメントの規準化パ ワースペクトル密度の無次元弾性限界風速 $U_{e}^{*}$ に対応する值, $C\left(S_{m e}^{*}, h\right): S_{m e}^{*}, h$ の関数

このR $R_{e}$ により(7)式を規準化すると(9)式が得られる。

$$
\begin{aligned}
& \ddot{q}_{n}^{* *}+4 \pi h \dot{q}_{n}^{* *}+(2 \pi)^{2} \check{Q}^{* *}\left(q_{n}^{* *}\right)=\frac{1}{U_{e}^{* 2} C_{m}^{\prime} C\left(S_{m e}^{*}, h\right)} U_{H}^{* 2} C_{m n} \\
& \text { ただし、 } q^{* *}=q^{*} / R_{e}
\end{aligned}
$$

(9)式は、 $h, C\left(S_{m e}^{*}, h\right), U_{e}^{*}, U_{H}^{*}, C_{m n}$ が変わらなければ、, $q^{* *}$ が $R_{e}$ に依存しない、つまり、q*は $R_{e}$ に比例することを示している。また、 (8)式は、 $R_{e}$ と $\rho_{s}$ は反比例の関倸になることを示している。すなわち、 無次元弾性限界風速を固定して $R_{e}$ を変化させるということは、それ に反比例して $\rho_{s}$ を変化させるということと同じである。他方、同様 にして、エネルギー応答量 $E^{*} は R_{\rho}^{2}$ に比例する。

\section{2 高次振動の影響}

先ず、文献(14)の手法に従い算出したモーダルエネルギー比 $\Omega_{j}$ によ

り高次振動の影響を検討する。

モーダルエネルギーE $\tilde{E}_{j}$ は各振動次のモーダルせん断力 $\{\tau\rangle_{j}$ $\left(=[K]\{u\}_{j},\{u\}_{j}: j\right.$ 次振動モードベクト ル)のなす仕事と定義され、(10)式で表され る。また、モーダルエネルギー比 $\Omega_{j}$ は各 振動次のモーダルエネルギーをその総和 で除した值であり、(11)式で表される。

$$
\begin{aligned}
& E_{j}=\{\tau\}_{j}^{T} \int_{0}^{t} r_{j}\{d u\} \\
& \Omega_{j}=\frac{E_{j}}{\sum_{i=1}^{k} E_{i}} .
\end{aligned}
$$

ただし、 $r_{j}:$ 係数, $\{d u\}$ : 層間変形の時 間に関する増分べクトル。
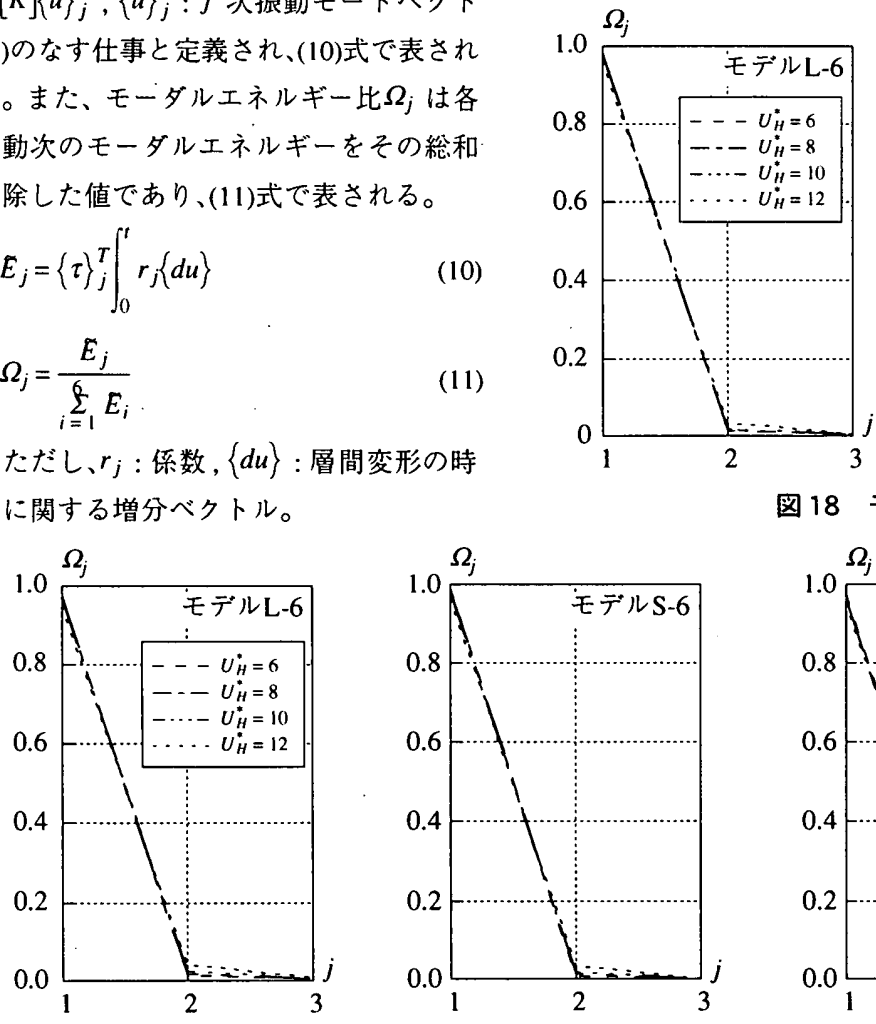

図 18 モータルエネルギー比（初期剛性比例型減衰）

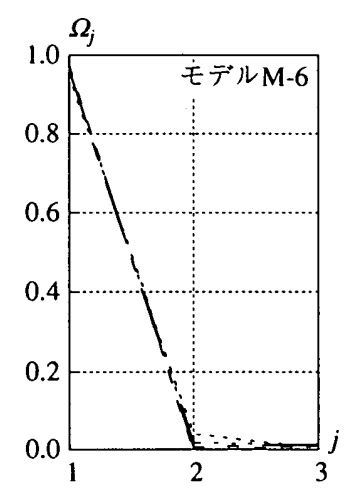

図 19 モーダルエネルギー比（レイリー型減衰）

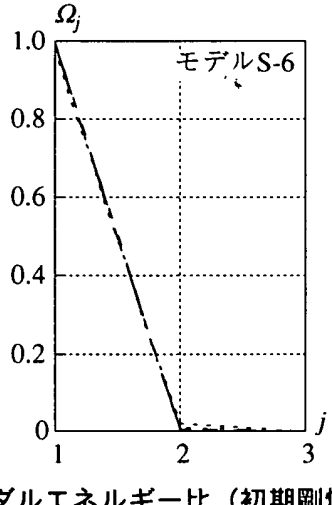

図 18 に無次元弾性限界風速 6 の場合の基本モデルのモーダルエネ ルギー比を示す。いずれのモデルにおいても無次元風速の增加に関ら ず、1 次振動成分の占める割合は $90 \%$ 以上であり、2 次以降の振動成 分の占める割合は小さい。この傾向は他の無次元弾性限界風速および $\alpha=0.25$ の場合においても同様である。次に、図19に基本モデルの減 衰係数をレイリー型とした場合の無次元弾性限界風速 6 についての モーダルエネルギー比を示す。モデル L-6, モデル S-6では、2次振動 の占める割合が初期剛性比例型に比べ若干大きく、モデルM-6では、 3次振動の占める割合が大きくなるが、いずれも、次振動の占める割 合に比べて小さい。

因に、図 20 に弾塑性応答時の無次元弾性限界風速 6 , 無次元風速 8 における基本モデルの頂部応答変位のパワースペクトル密度を示す。 いずれのモデルにおいても1次固有振動数で鋭いピークを示してお ク、2次以降の高次振動数におけるピークは小さく、高次振動の影響 は小さい。

続いて、6質点系と 1 質点系の応答量の比較により高次振動の影響 を明らかにする。結果は全て6質点系の応答量と1質点系の応答量の 比で評価する。なお、多質点系においても弾性エネルギーは総入力エ ネルギーに比べ微少であるため、総入力エネルギーは弾性応答では $E_{E}^{*}=E_{E h}^{*}$ 、弾塑性応答では $E_{P}^{*}=E_{P h}^{*}+E_{P p}^{*}$ とする。また、6 翼点系に おける建築物全体の入力エネルギー $E_{\text {all }}^{*}$ は、各層の入力エネルギー $E_{i}^{*}$ の総和 $\left(\sum_{i=1}^{\infty} E_{i}^{*}\right)$ とする。図 21,22 に弾性応答時の最大応答変位比: 総入力エネルギー比を示す。いずれのモデルにおいても無次元風速に 関係なく両質点系は一致している。図23２8に弾塑性応答時の無次 元弾性限界風速 6 の場合の最大応答变位比、応答变位の標準偏差比、 レベルクロッシング数比、総入力エネルギー比、減衰エネルギー比、 塑性歪エネルギー比を示す。ここで、U $U_{e}^{*}$ は1質点系における無次元
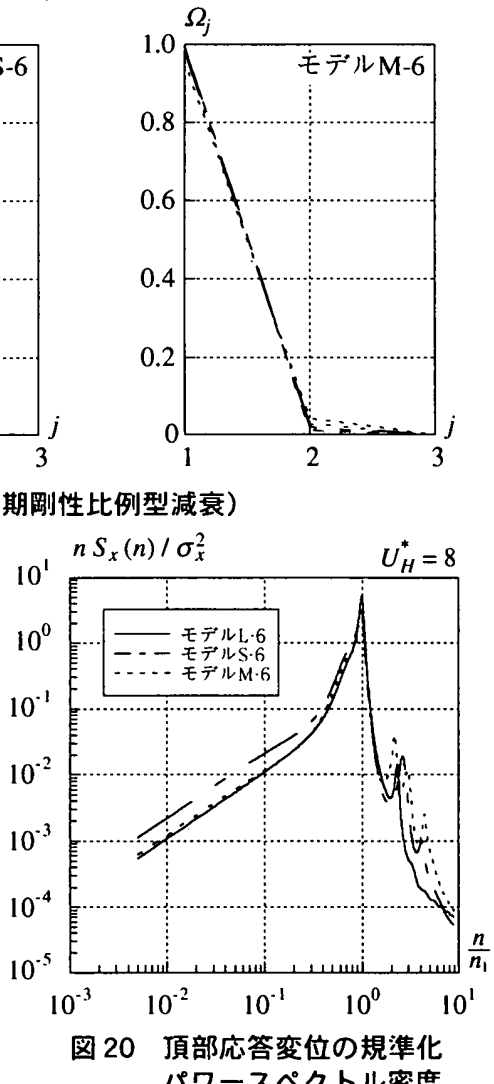
パワースペク 
弾性限界風速を表しており、多質点系での無次元弾性限界風速U $U_{e}^{*}$ は、 モデル L-6, モデルM-6では、 $U_{\rho}^{*}=1.02 U_{\rho}^{*}$ （モデルM-6の fit 型に对し

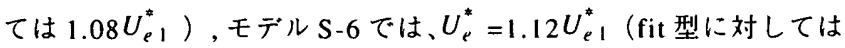
$\left.1.05 U_{e 1}^{*}\right)$ となる。モデルしでは全ての応答比において両質点系は一 致している。モデルSでは塑性歪エネルギー比に大きな差異が見られ るが、その他の応答比に関しては概ね 10\%以内の差異である。ここ で、モデルS-1fに着目すると、モデルS-1 と比較して全ての応答比に おいて差異は滅少している。従って、モデル Sでの差異は振動系の復元力特性の違いによ る影瑤と考えられる。モデルMでは隇衰エ ネルギー比および塑性歪エネルギー比に大 きな差異が見られる。また、モデルM-1fでは モデルS-1fのような顕著な改善は見られない。 ここで、図29にモデル M-6の総入力エネル ギー比分布 $E_{P_{i}}^{*} / E_{P \text { all }}^{*}$ を示すが、第4層にエネ ルギーが集中する配分特性となっている。因 に、エネルギー集中が生じないように、モデ ルM-6の上部 2 層の弾性限界層間変形角も1/ 300としたモデル(図29中仓)とモデルM-1を比 皎すると(図23～28中仓)、全ての応答比にお いて両質点系の差異は概ね10\%以内となる。 従って、モデルM-1やモデルM-1fでの差異は エネルギー集中による影響と考えられる。

なお、初期渆性に対する2次剛性の比 $\alpha$ を 0.25 とした場合についても、モデルS-6,モデ ルM-6の結果が若干小さめとなるが、概ね 同樣の結果が得られる。また、減衰係数をレ イリー型とした場合も、いずれのモデルに おいても、初期剛性比例型に比べ、塑性歪工 ネルギー比は大きく、隇衰エネルギー比は 小さくなるが、その差は小さい。

\section{3 缓钩モードの变化}

基本モデルを対象に塑性化による振動 モードの変化について検討する。ここでは、 出来るだけ広い風速筙囲における風速変化 とモード変化の関係を明らかにするため、 図 30 に(12)式より算出した無次元弾性限界 風速 4 の場合の 1 次振動モードを示す。図 中、” original” は弾性応答時の 1 次振動モ一 ドを示している。

$u_{1}\left(h_{i}\right)=\frac{\operatorname{Re}\left[S_{q}\left(n_{1}, h_{H}, h_{i}\right)\right]}{S_{q}\left(n_{1}, h_{H}\right)}$

ただ、、 $S_{q}\left(n_{1}, h_{H}\right), S_{q}\left(n_{1}, h_{H}, h_{i}\right):$ 頂部質点 の応答変位のパワースペクトル密度と頂部 質点と質点iの応答変位のクロススペクト ル密度の振動数 $n_{1}$ における值, Re [-] : 実数 部を表す。

いずれのモデルにおいても無次元風速の増 加に伴い振動モードは変化する傾向にある

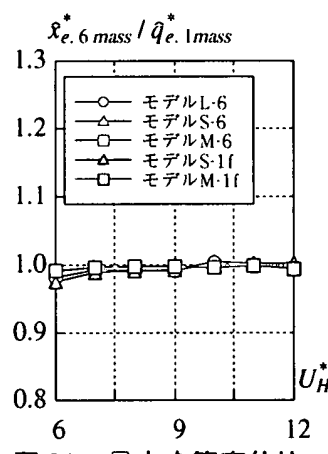

图 21 踶大応答变位比 (弾栓席答)

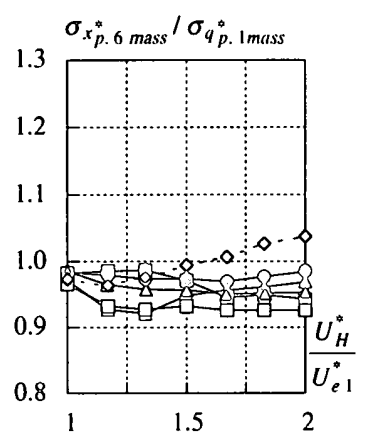

图 24 応答变位の徱集偏差比 图

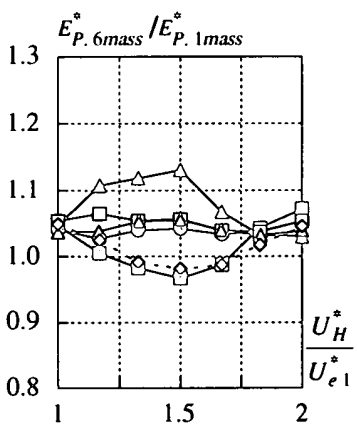

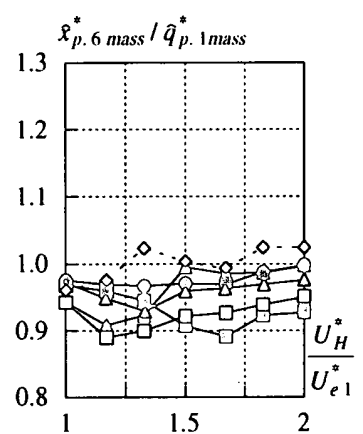

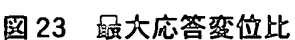

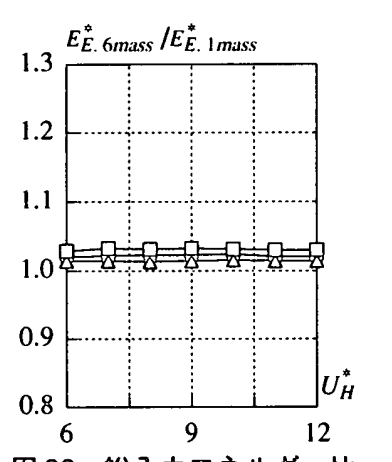

图 22 棇入カエネルギー比 (匴懏席答)

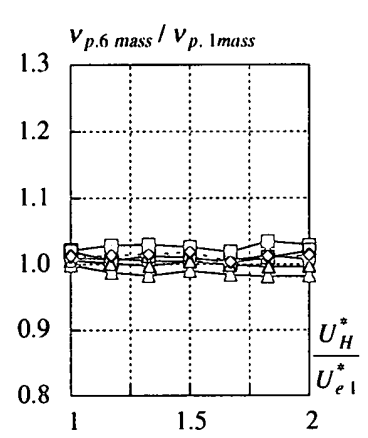

图 27 檓衰エネルキー比

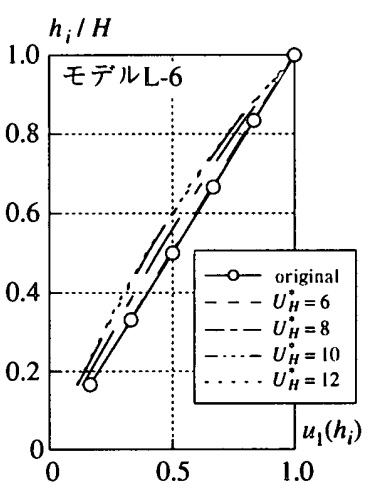

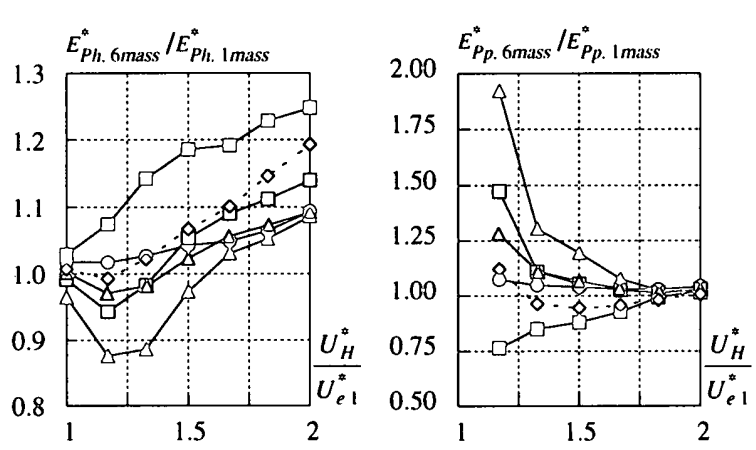

が、1.8U $U_{e}^{*} \sim 2.0 U_{e}^{*}$ での変化は小さい。因に、この風速範囲はモデルの 4.4 モード消正係新の適用管

弾性応答解析において多用され、(13)式で定義されるモード補正係数 15 ) の弾塑性振動に対する適用性について、モーダル1次の1質点系応答

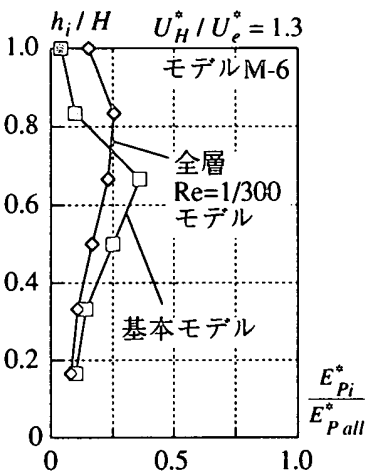

28 塑等昰エネルキー比
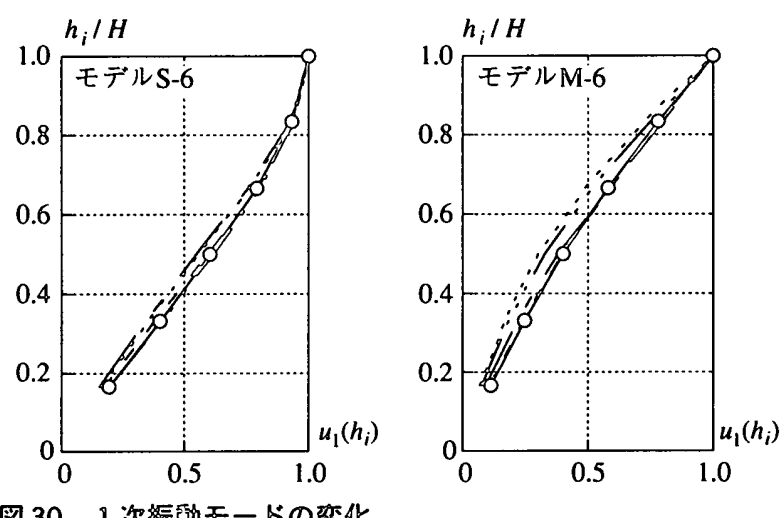


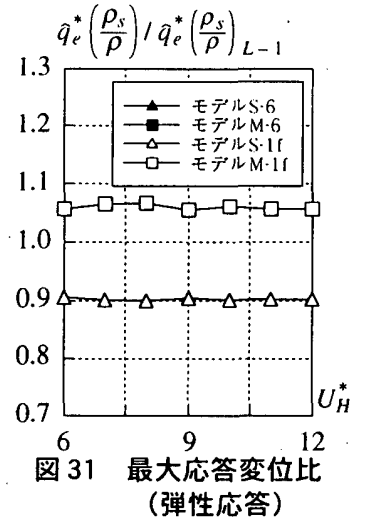

量の比較により検討する。ただし、曲げ型振動系については、(14)式の ような近似式が用意されているので、(14)式による。また、応答結果の比 較は全て他のモデルの応答量をモデルL-1で除した值とし、モードの違 いにより構造密度が異なることから、構造密度で規準化して評価する。

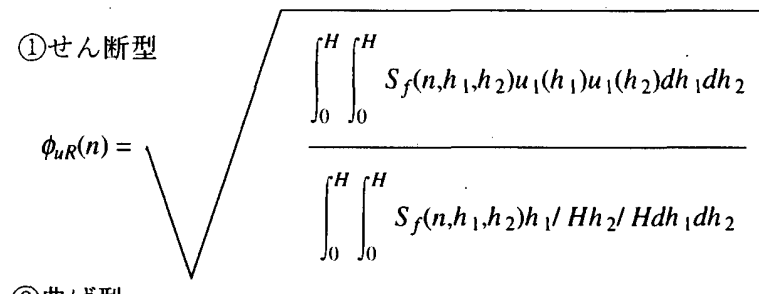

(2)曲げ型

$$
\phi_{u R}=\sqrt{\left(\frac{2+\gamma}{1+\beta+\gamma}\right)^{2} \frac{1+c_{0} /(2.8+\gamma)}{1+c_{0} /(1.8+\beta+\gamma)}}
$$

たたし、、 $\beta$ : 振動モードを付 $(z)=(h / H)^{\beta}$ と仮定した場合の指数, $\gamma$ : 建築物の単位高さ当たりに作用する変動風力の標準偏差 $\sigma_{f}$ の高さ方向 分布を $\sigma_{f}=\sigma_{f R}\left(h / h_{R}\right)^{\gamma}$ と仮定した場合の指数, $\sigma_{f R}: \sigma_{f}$ の代表高さ $h_{R}$ における值, $c_{0}$ : 変動風力の高さ方向の疑似コ・コヒーレンス（クロス スペクトル密度の実部を代表高さのパワー スペクトル密度で除した量) $R_{f y}^{*}\left(n, h_{1}, h_{2}\right)$ を $R_{f y}^{*}\left(n, h_{1}, h_{2}\right)=\exp \left(-c\left|h_{1}-h_{2}\right|\right)$ と仮定 した場合の倸数 $c$ の、 $n=n_{0}$ としたときの 値。

比較のために、先ず、図31,32に弾性応 答時の最大応答変位比および総入力エネル ギー比を示す。いずれの応答比において も、無次元風速に関らず概ね一定值を示し ており、モデル L-1 との差は、最大応答変 位比においてモデル S-1, モデル S-1fが 0.9 倍、モデルM-1,モデル M-1fが1.07倍であ ク、総入力エネルギー比はそれぞれの2乗 倍である。図 33,34に弾塑性応答時の無次 元弾性限界風速6の場合の最大応答变位比 および総入力エネルギー比を示す。弾性応 答と同様に無次元風速に関らず概ね一定值 を示している。また、(13),(14)式によりモー ド補正係数を算出し、モード補正を行う と、解析値との誤差はせん断型で概ね $15 \%$ 以内、曲げ型で 10\%以内となる。以上の傾 向は他の無次元弾性限界風速の場合におい

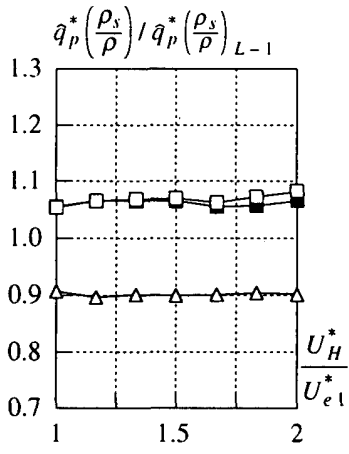

図 33 最大応答変位比

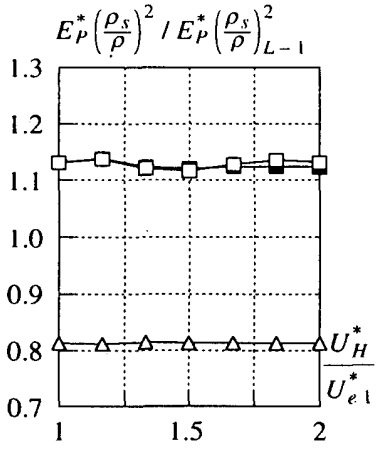

図 34 総入カエネルギー比

\section{ても同様である。}

これより、1質点弾塑性系の応答についても、モード補正倸数とい う考え方が導入できる。

\section{5 エネルギー分布}

基本モデルを対象に剛性分布とエネルギー分布の関係を検討する。 先ず、図35に弾性応答時の総入力エネルギー比分布 $E_{E}^{*}{ }_{i} / E_{E \text { all }}^{*}$ を示 す。いずれのモデルにおいても無次元風速に関係なく同様のエネル ギー分布を示している。図中の○印は次式で与えられる弾性応答にお ける各層の総入力エネルギー $E_{E i}$ により求めたものであるが、解析值 とよく一致している。

$$
E_{E i}=4 \pi \zeta k_{i} \sigma_{q e i}^{2}\left(\frac{v_{e i}}{n_{1}}\right) v_{e i} T
$$

ただし、 $k_{i}$ : 各層の剛性, $\sigma_{q e i}$ : 層間応答变位の標準偏差, $v_{e i}$ : 層間 応答変位のレベルクロッシング数。

(15)式において、各層のレベルクロッシング数が高さ方向に等しけれ ば、総入力エネルギーは各層の剛性と層間応答変位の分散に依存する值
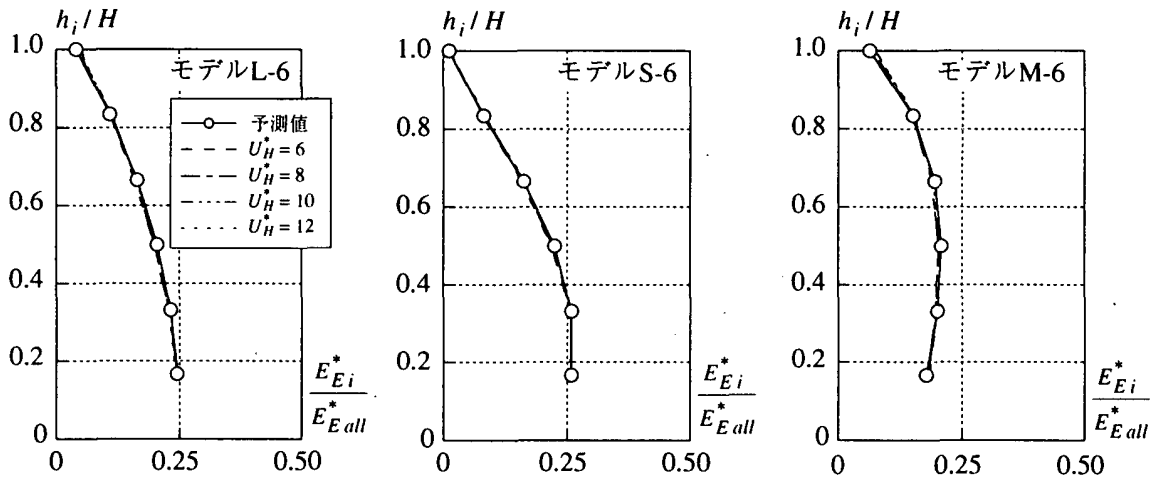

図 35 総入カエネルギー比分布（弾性応答）
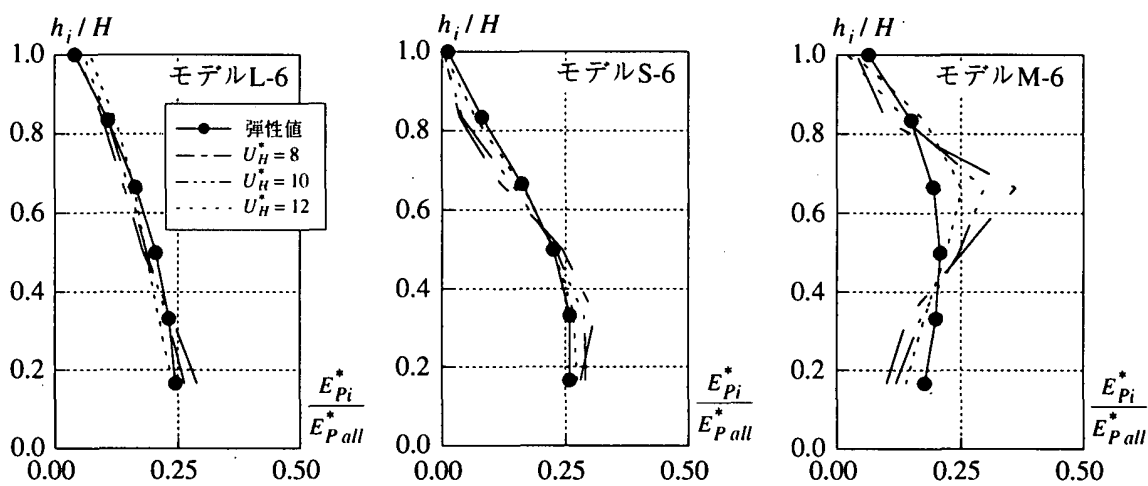

図 36 総入カエネルギー比分布（弾塑性応答） 
となる。ここで、前述の結果より1次振動が卓越することから、総入力 エネルギー比分布は1次振動モード $u_{1}\left(h_{i}\right)$ から得られる層間変位 $q_{i}((16)$ 式参照)と各層の剛性を用いて(17)式のように予測できると考えられる。

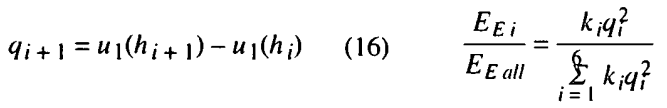

次に図 36 に弾塑性応答時の無次元弾性限界風速 6 の場合の総入力 エネルギー比分布 $E_{P i}^{*} / E_{P \text { all }}^{*}$ を示す。図中の○印は弾性応答時の結果 を示している。モデルし-6では無次元風速によって若干違いが見られ るが、概权弾性応答時のエネルギー分布と一致している。モデル S-6 およびモデルM-6では、まず初めに塑性化した層にエネルギーが集中 し、風速の増加に伴い他の層も塑性化しはじめ、集中していたエネル ギーが各層に分配され、弾性応答時のエネルギー分布に一致してく る。一致する風速はモデルの違いにもよるが概ね $1.8 U_{e}^{*} \sim 2.0 U_{e}^{*}$ であ る。図 37,38に無次元弾性限界風速 6、無次元風速 8 の場合の各層の 塑性率 $\mu$ と累積塑性変形倍率 $\eta$ を示す。ここで、塑性率は各層層間変 位の最大值をその層の降伏变形量で除した值を表し、累積塑性変形倍 率は各層ごとに正側または負側のどちらか大きいほうの塑性変形量の 累積值を降伏変形量で除した值である。モデルL-6は全層ほほ同時に 塑性化することから、塑性率および累積塑性変形倍率ともに高さ方向に 概ね一定である。モデルS-6では第6層は弾性であるため累積塑性変形 倍率は0であるが、塑性化が先行する第1層～第3層の塑性率および累 積塑性変形倍率が大きくなっている。モデルM-6は第4層にエネルギー

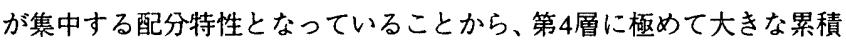
塑性変形倍率を生じており、その他の層では非常に小さい值となってい る。以上の性状は、初期剛性に対する 2 次剛性の比 $\alpha$ を 0.25 とした場合 および減衰係数をレイリー型とした場合についても同様である。

\section{5. 籍ひ}

本報では、ロッキング型, せん断型および曲げ型の各高層建築物の 風直角方向振動について等価せん断モデルによる多質点弾塑性応答解 析を行い、高次振動の影響、塑性化による振動モードの変化、1 質点 系による応答評価の妥当性、弾塑性応答に対する「モード補正係数」 の適用性、入力エネルギーの分布性状等について検討した。また、無 次元弾性限界風速6の場合について、高次振動に対する2次剛性比お よび減衰の影陌について検討を行った。確認された知見を要約すると 次の通りである。

(1)弾性応答および弾塑性応答ともに高次振動の影響は小さい。 (2)高次振動に対する2次剛性比および減衰の影響は小さい。 (3)塑性化による振動モードの変化は小さい。

(4) 1 質点モデルによる応答評価は妥当である。ただし、1 質点系への モデル化の際、振動系の復元力特性に留意すること。特に、曲げ型 建築物については、降伏酎力あるいは降伏変形量の分布によっては エネルギー集中を生じ、一質点モデルによる評価が不適切になるこ とがあるため、モデル化に際して注意が必要である。

(5)弾塑性応答についても「モード補正係数」が適用できる。

(6)弾性応答時および弾塑性応答時の総入力エネルギー比分布は、1次 振動が卓越することから(17)式により予測できる。ただし、せん断 型建築物の塑性化初期段階や曲げ型建築物に見られるようなエネル ギー集中を生じる場合については適用できない。

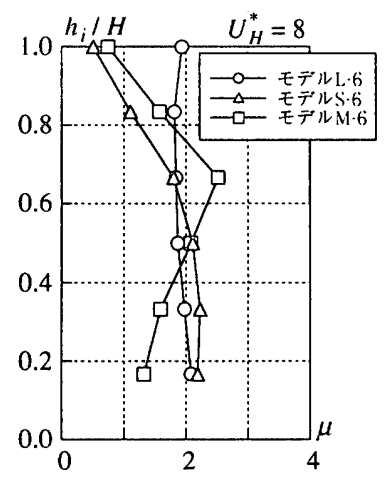

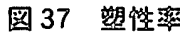

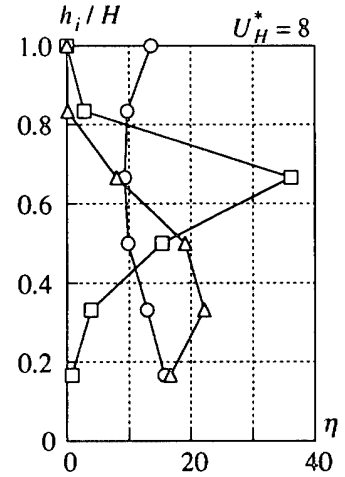

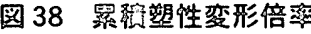

『謝辞】

本論文の作成に当たり多大な協力を頂いた、東急建設(株)技術研究所 栗田剛氏、ならびに神奈川大学大学院生三石正史氏に心より謝意を表し ます。な㧍、本研究は、建設省総合技術開発プロジェクト「新建築構造 体系の開発」風荷重 SWG の研究の一貫として、社団法人建築研究振興 協会より研究助成を頂いている。ここに、記して感謝の意を表します。

\section{渗势立献}

1) 大熊武司,辻田 修,早部安弘:履歷ダンパーを用いた建築物の強風時応答性 状,シンポジゥム「付震設計の1つの新しい方向」論文集,同シンポジウム実行 委員会,1995年10月,東京

2) 迁田修, 早部安弘, 大熊武司, 和田 章: 弹塑性権造物の風応答性状ならび にその予測に関する研究，(その1）風直角方向振動の場合,日本建築学会情造 系論文集,N0481,1996 年 3 月

3) 辻田 修, 早部安弘, 大熊武司, 和田 章: 弹塑性棈造物の風応答性状ならび にその予測に関する研究，(その2) 風方向振動の場合,日本建筑学会構造系論 文集, No485,1996 年 7 月

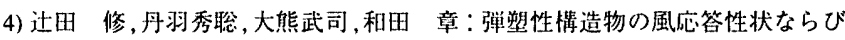
にその予測に関する研究，(その3）提案予測手法の風速変化に対する適用性， No493,1997 年 3 月

5) 辻田修, 早部安弘, 乎羽秀聡, 大熊武司, 和田章: 弾塑性構造物の風応答 性状ならびにその予測に関する研究，(その4) 多質点系モデルへの展開、日本 建筑学会構造系詇文集, No498,1997 年 8 月

6) 山崎真司, 吉川 假：高居建築物の風力によるエネルギー応答性状,第 14 回 風工学シンポジウム論文集, 1996 年12月, 東京

7) 安井八紀, 丸川比佐夫，田村幸雄，小林義幸,馬場泰通：8層1 スパン釷構造 建策物の風による弾塑性応答解析, 第 14 回風工学シンポジウム論文集,1996 年 12 月, 束京

8）大熊武司，栗田 㓝,二宮正行：エネルギーの釣合いに基つくく高層建築物の風 直角方向弾塑性振動の応答予測,第14回風工学シンポジウム論文集,1996 年 12 月,東京

9) 大熊武司，二宮正行，三石正史：高層建築物の風直角方向振動についての一質 点弾塑性応答解析, 日本建築学会大会学術溝演梗慨集（関東）,1997年 9 月 10) 大熊武司,向 秀元,木村充幸,栗田 岡: 高層建築物の風応答スペクトルにつ いてのケーススタデイ、日本建築学会大会学術講演梗概集（東海）,1994 年9月

11）大熊武司，向秀元，丹羽秀聡，寺本隆幸：動的天秤デー夕を利用した高層 建管物の層風力シミュレーションに用いる時空相関モデル,第13回風工学シン ポジウム論文集, 1994 年 12 月, 東京

12) 秋山 宏：建築物の耐震極限設計,東京大学出版会,1987 年 9 月

13) 柴田明德：最新酎荊㧼造解析,森北出版, 1981 年 6 月

14）桑村 保, 鈴井康正：強震を受ける弾塑性多質点系のモータルエネルギー 日本建筑学会搆造系論文集, No465,1994 年 11 月

15) 大熊武司，神田 䐓，田村幸踓：建築物の耐風設計，麇島出版会,1996 年 3 月 16）大熊武司，二宮正行，增井友城：多質点弾塑性系としての高層建築物の風応 答特性 風直角方向振動の場合その 1 その 3 , 日本建築学会大会学術講演梗 概集（関東）,1997 年 9 月

（1997年 9 月 9 日原稿受理, 1998年 2 月 20 日採用決定 